\title{
Effects of land use and water quality on greenhouse gas emissions from an urban river system
}

\author{
Long $\mathrm{Ho}^{1 *}$, Ruben Jerves-Cobo ${ }^{1,2,3}$, Matti Barthel ${ }^{4}$, Johan $\mathrm{Six}^{4}$, Samuel Bode ${ }^{5}$, Pascal Boeckx ${ }^{5}$, Peter \\ Goethals ${ }^{1}$ \\ $5 \quad{ }^{1}$ Department of Animal Sciences, Ghent University, Gent, Belgium; \\ ${ }^{2}$ PROMAS, Universidad de Cuenca, Cuenca, Ecuador; \\ ${ }^{3}$ BIOMATH, Department of Data Analysis and Mathematical Modelling, Ghent University, Gent, Belgium \\ ${ }^{4}$ Department of Environmental System`s Science, ETH Zurich, Zurich, Switzerland; \\ ${ }^{5}$ Department of Green Chemistry and Technology, ISOFYS Group, Ghent University, Gent, Belgium
}

10 Correspondence to: Long Ho (Long.TuanHo@UGent.be)

\begin{abstract}
Rivers act as a natural source of greenhouse gases (GHGs) that can be released from the metabolisms of aquatic organisms. Anthropogenic activities can largely alter the chemical composition and microbial communities of rivers, consequently affecting their GHG emissions. To investigate these impacts, we assessed the emissions of $\mathrm{CO}_{2}, \mathrm{CH}_{4}$, and $\mathrm{N}_{2} \mathrm{O}$ from Cuenca urban river system (Ecuador). High variation of the emissions was found among river tributaries that mainly

15 depended on water quality and neighboring landscapes. By using Prati and Oregon Indexes, a clear pattern was observed between water quality and GHG emissions in which the more polluted the sites were, the higher were their emissions. When river water quality deteriorated from acceptable to very heavily polluted, their global warming potential (GWP) increased by ten times. Compared to the average estimated emissions from global streams, rivers with polluted water released almost double the estimated GWP while the proportion increased to ten times for very heavily polluted rivers. Conversely, the GWP

20 of good-water-quality rivers was half of the estimated GWP. Furthermore, surrounding land-use types, i.e. urban, roads, and agriculture, significantly affected the river emissions. The GWP of the sites close to urban areas was four time higher than the GWP of the nature sites while this proportion for the sites close to roads or agricultural areas was triple and double, respectively. Lastly, by applying random forests, we identified dissolved oxygen, ammonium, and flow characteristics as the main important factors to the emissions. Conversely, low impact of organic matter and nitrate concentration suggested a

25 higher role of nitrification than denitrification in producing $\mathrm{N}_{2} \mathrm{O}$. These results highlighted the impacts of land-use types on the river emissions via water contamination by sewage discharges and surface runoff. Hence, to estimate of the emissions from global streams, both their quantity and water quality should be included.
\end{abstract}

\section{Introduction}

Via the biogeochemical cycles of carbon (C), nitrogen (N) and water, (in)organic carbon and nitrogen compounds are added 30 from terrestrial biosphere to inland water bodies (Meybeck, 1982;Schimel, 1995). These compounds can be transformed into greenhouse gases (GHGs), such as $\mathrm{CO}_{2}, \mathrm{CH}_{4}$, and $\mathrm{N}_{2} \mathrm{O}$, by microbial degradation and metabolisms, making rivers an active 
https://doi.org/10.5194/bg-2020-311

This is just a preview and not the published preprint.

(C) Author(s) 2020. CC-BY 4.0 License.

\section{(c) $\underset{\text { BY }}{\text { (i) }}$}

source of GHGs to the atmosphere (Butman and Raymond, 2011;Raymond et al., 2013; Ho and Goethals, 2020a). Particularly, $\mathrm{CO}_{2}$ and $\mathrm{CH}_{4}$ are released mainly via the decay of organic matter during bacterial decomposition processes while nitrifying and denitrifying microorganisms are considered major generators of $\mathrm{N}_{2} \mathrm{O}$ in inland water bodies (Daelman et al., 2013). Besides acting as a natural source of GHGs, rivers also serve as conduits for the GHGs released from groundwater and sediments to the atmosphere (Hotchkiss et al., 2015). In total, it was estimated from global streams and rivers that their $\mathrm{CO}_{2}$ emissions were $1.8 \pm 0.25 \mathrm{Pg} \mathrm{C} \mathrm{yr}^{-1}$ (Raymond et al., 2013) while the size of inland water $\mathrm{CH}_{4}$ and $\mathrm{N}_{2} \mathrm{O}$ evasions were 26.8 $\mathrm{Tg} \mathrm{C} \mathrm{yr}^{-1}$ and 1.26 Tg N yr ${ }^{-1}$, respectively (Kroeze et al., 2005;Beaulieu et al., 2011;Stanley et al., 2016).

Besides the natural inputs from terrestrial ecosystems, anthropogenic activities such as fertilization or wastewater discharges

40 can lead to elevated nutrient inputs which in turn can lead to an increase in GHG emissions from inland water bodies. In urban areas, land-use changes and the discharges from sewers and wastewater treatment plants (WWTPs) have deteriorated river water quality by causing extensive modification in biochemical reactions and hydro- and morphology characteristics (Damanik-Ambarita et al., 2018). These anthropogenic sources were estimated to account for at least $10 \%$ of the global $\mathrm{N}_{2} \mathrm{O}$ emissions from rivers to the atmosphere (Beaulieu et al., 2011). While the concern about environmental impacts and human

45 health from the discharges has extensively been investigated, very little attention has been paid for their impacts on GHG emissions. National standards of the effluent discharge of WWTPs have been set to protect human health and the environment; however, their impacts on receiving rivers with respect to the GHG emissions have been absent.

Although the acknowledgment of the GHG emissions from rivers was given earlier (Meybeck, 1982;Kling et al., 1992), the progress of its mechanistic understanding is still facing many challenges (Goldenfum, 2012). The challenges derive from the complex biological processes in the water column of rivers, their intricate interactions with terrestrial ecosystems and various human activities along the rivers. Due to the current limited understanding, a strong spatial variation of GHG emissions was frequently found in rivers without a clear explanation (Musenze et al., 2014). Recently, the variation of GHG emissions was referred to as a function of river sizes and their connectivity with terrestrial ecosystems (Hotchkiss et al., 2015;Raymond et al., 2013;Rosamond et al., 2012). Other studies indicated that agricultural run-offs have increased the

55 GHG emissions from rivers (Smith et al., 2017), while recent findings showed that urban infrastructure may contribute to the elevated GHG emissions from urban rivers (Kaushal et al., 2014;Gallo et al., 2014). However, it remains vague how these different landscapes affect the GHG emissions from the connected rivers and different water qualities of the rivers can impact their contribution to climate change. From this perspective, this study aims to clarify the link between neighboring land-use types, water quality, and the GHG emissions of river systems. To this end, we conducted a sampling campaign at

60 the five tributaries of Cuenca river urban system, collecting information about not merely the concentrations of the three main GHGs, i.e. $\mathrm{CO}_{2}, \mathrm{CH}_{4}$, and $\mathrm{N}_{2} \mathrm{O}$, but also physiochemical, hydromorphological, and meteorological variables. Subsequently, at each sampling site, we calculated Prati and Oregon water quality indexes and categorized different types of adjacent landscapes to investigate the impacts of these factors on the variation of the GHG emissions. Thereby, the study was able to calculate how the contribution of the rivers to climate change changed over different water quality categories and 
https://doi.org/10.5194/bg-2020-311

This is just a preview and not the published preprint.

(c) Author(s) 2020. CC-BY 4.0 License.

(c) (i)

65 land use types. Furthermore, statistical analysis and random forests were applied to investigate the spatiotemporal variation of the GHG emissions and identify the main important factors of the variation.

\section{Materials and Methods}

\subsection{Study area}

The study area is located at the Cuenca River basin situated in the southern province of Azuay in the Andes of Ecuador. The

70 basin is composed of five main tributaries, i.e. Cuenca, Tarqui, Yanuncay, Tomebamba, and Machangara Rivers. The study area is $223 \mathrm{~km}^{2}$, representing $13 \%$ of the Cuenca River basin. The city of Cuenca has a population of approx. 401.000 inhabitants in 2019. Two natural reserves are also located upstream from the Cuenca River basin: Cajas National Park and the Machangara-Tomebamba protected forest. Both are water sources for the Tomebamba, Yanuncay and Machangara Rivers (Jerves-Cobo et al., 2018b). The mean altitude of the study area is $2655 \mathrm{~m}$ a.s.l. The annual average air temperature is

$7516.3{ }^{\circ} \mathrm{C}$ and the average rainfall is about $879 \mathrm{~mm}$ per year (Jerves-Cobo et al., 2018a). The rainy season starts from the middle of February until the beginning of July and from the second half of September until the first two weeks of November, while the rest of the year constitutes the dry season (Jerves-Cobo et al., 2020b). The area of Cuenca, Machangara, Tarqui, Tomebamba, and Yanuncay is 95.92, 111.19, 138.98, 113.03, $113.81 \mathrm{~km}^{2}$, respectively.

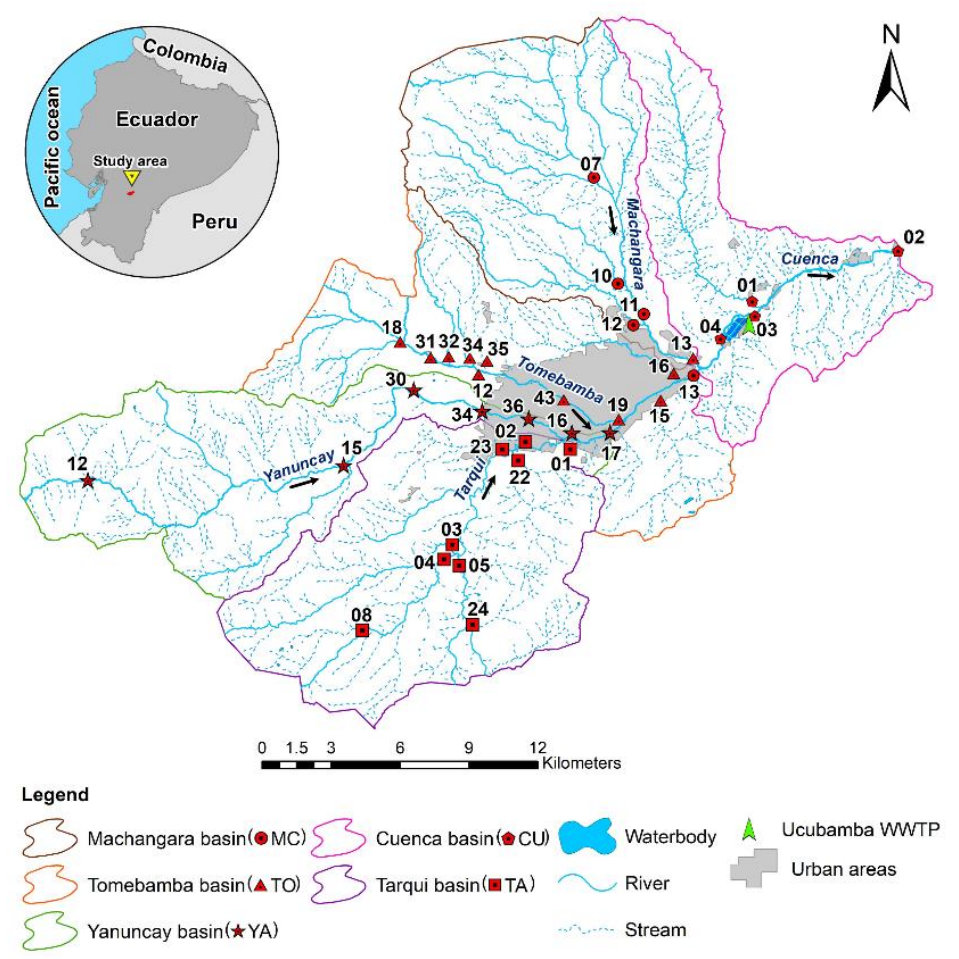

80 Figure 1. Location of the study area in Ecuador and 36 sampling sites at the Cuenca urban river system. 
https://doi.org/10.5194/bg-2020-311

This is just a preview and not the published preprint.

(C) Author(s) 2020. CC-BY 4.0 License.

\subsection{Field measurements}

A sampling campaign was conducted from 17/09/2018 to 21/09/2018. During this period, samples were collected from 9.00 to 18.00. This course of time covers the whole period of daylight in Cuenca, ensuring the investigation of temporal effects on oxygen variation, hence, on the GHG emissions. 36 sites were sampled in the Cuenca river basin, splitting into the five basins covering the whole urban river area as well as the river sources. Besides assessing the emissions of $\mathrm{CO}_{2}, \mathrm{CH}_{4}$, and $\mathrm{N}_{2} \mathrm{O}$, we also gathered physiochemical, hydro-morphological, and meteorological data. Specifically, water temperature, pH, dissolved oxygen (DO), turbidity, total dissolved solid (TDS), and chlorophyll $a$ were determined by a handheld multiprobe (Aquaread-AP5000 version 4.07). Calibration was performed prior to sampling and supplemented with a regular check after sampling.

90 Water samples from all sampling sites were collected and stored in cool and dark containers and then preserved in a refrigerator before being analyzed for other variables in the Water and Soil Quality Analysis Laboratory at Cuenca University. Particularly, ammonium $\left(\mathrm{NH}_{4}{ }^{+}\right)$, nitrite $\left(\mathrm{NO}_{2}^{-}\right)$, nitrate $\left(\mathrm{NO}_{3}^{-}\right)$and orthophosphate $\left(\mathrm{PO}_{4}{ }^{3-}\right)$ were determined spectrophotometrically (low-range Hach test kits with Hach DR3900). Moreover, water samples were kept frozen until shipment to Belgium for further analyses, i.e. biochemical oxygen demand (BOD 5$)$, chemical oxygen demand (COD), total

95 nitrogen (TN), and total phosphorus (TP). Details of the Hach kits can be found in the Supplementary Material S1. Hydromorphological information of the sites and their surroundings were collected, including land use, macrophytes, riparian vegetation, channel types, flow types, and sediment, via a modified field protocol of Jerves-Cobo et al. (2018b). Note that land use types surrounding the sampling sites were assessed using the modified field protocol based on the Australian River Assessment System physical assessment protocol (Parsons et al., 2002) and the United Kingdom and the Isle of Man River

100 Habitat Survey (Raven et al., 1997). In total, 17 variables were measured following different categories (Supplementary Material S2). River depth and velocity were measured at three points at each sampling site, two close to the riverbanks and one in the middle of the river. Meteorological data, including air temperature, solar radiation, rainfall, and wind speed, were obtained from the meteorological station of the University of Cuenca $\left(-2.9050372^{\circ},-79.0124267^{\circ}\right), 10 c a t e d ~ 7.8 \mathrm{~km}$ away from the Ucubamba WWTP and $0.7 \mathrm{~km}$ away from the city center.

105 To facilitate data accessibility, analysis, and visualization, we developed an interactive application using R Shiny package (Chang et al., 2015). This application allows customization of the application's user interface to provide an elegant environment for displaying user-input controls and simulation outputs (Wojciechowski et al., 2015). In short, the outputs can be instantaneously updated with the inputs, hence, the users can access, analyze, and visualize the collected data in a quick, flexible, and informative way. Detailed values of all variables in the 36 sampling sites are available online at https://waterresearch.shinyapps.io/GHG_Cuenca/. 
https://doi.org/10.5194/bg-2020-311

This is just a preview and not the published preprint.

(c) Author(s) 2020. CC-BY 4.0 License.

(c) (i)

\subsection{Dissolved gas concentrations}

Dissolved GHG concentrations $\left(C_{a q}\right)$ were measured using the headspace equilibration technique. Before the field campaign, $12 \mathrm{~mL}$ vials with airtight septa (Exetainer ${ }^{\circledR}$, Labco Ltd, High Wycombe, UK) were pre-conditioned with $50 \mu \mathrm{L}$ of $50 \% \mathrm{ZnCl}$ before capping and flushing with high purity $\mathrm{N}_{2}$ (Alphagaz 2, Carbagas, Gümlingen, Switzerland). At each sampling, $6 \mathrm{~mL}$ of water was pushed into the vials using a syringe after carefully removing air bubbles from the sample creating a headspace pressure inside the vial of ca. $2 \mathrm{~atm}$. The headspace was analyzed for concentrations of $\mathrm{CO}_{2}, \mathrm{CH}_{4}$, and $\mathrm{N}_{2} \mathrm{O}$ using gas chromatography (Bruker, GC-456, Scion Instruments, Livingston, UK) equipped with a thermal conductivity detector, flame ionization detector, and electron capture detector. The instrument was calibrated for each gas using several sets of standards within each measurement run. Dissolved gas concentrations $\left(\mu \mathrm{mol} \mathrm{L}^{-1}\right)$ were calculated by applying Henry's law, taking into account the vial volume and headspace.

$C_{a q}=p_{a} \times k_{h}$

where $k_{h}$ is Henry's constant adjusted for lab temperature $\left(\mathrm{mol} \mathrm{m}^{-3} \mathrm{~Pa}^{-1}\right)$ and $p_{a}$ is the partial pressure of the gas in the headspace $\left(\mathrm{Pa}^{-1}\right)$.

\subsection{Flux calculations}

125 The flux $\left(\mathrm{mg} \mathrm{m}^{-2} \mathrm{~d}^{-1}\right)$ from the river water to the atmosphere of the three gasses assessed was calculated according to the model on gas exchange between air and water of Liss and Slater (1974):

Flux $=k_{0} \times\left(C_{a q}-C_{e q}\right)=k_{0} \times\left(C_{a q}-p_{a} \times k_{h}\right)$

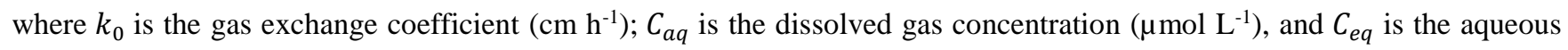
gas concentration in equilibrium with the atmosphere $\left(\mu \mathrm{mol} \mathrm{L}^{-1}\right) ; p_{a}$ is the partial pressure above the surface water at

130 equilibrium with atmosphere $\left(\mathrm{Pa}^{-1}\right) ; k_{h}$ is Henry's law constant corrected in a given temperature $\left(\mathrm{mol} \mathrm{m}^{-3} \mathrm{~Pa}^{-1}\right)$;

The gas exchange coefficient $k_{0}$ was calculated as follows.

$k_{0}=k_{600} \times(S c / 600)^{0.5}$

where $k_{600}$ is the gas exchange coefficient that was normalized to a common Schmidt number $(S c)$ of $600\left(\mathrm{~cm} \mathrm{~h}^{-1}\right)$. $S c$ is the Schmidt number that was calculated from an empirical third-order polynomial of Wanninkhof (1992) for the in situ water 135 temperature $\left(t_{w}\right)$ for different gases as follows.

$$
\begin{aligned}
& S c_{C O 2}=1911.1-118.11 \times t_{w}+3.4527 \times t_{w}^{2}-0.04132 \times t_{w}^{3} \\
& S c_{C H 4}=1897.8-114.28 \times t_{w}+3.2902 \times t_{w}^{2}-0.039061 \times t_{w}^{3} \\
& S c_{N 2 O}=2301.1-151.1 \times t_{w}+4.7364 \times t_{w}^{2}-0.059431 \times t_{w}^{3}
\end{aligned}
$$


https://doi.org/10.5194/bg-2020-311

This is just a preview and not the published preprint.

(c) Author(s) 2020. CC-BY 4.0 License.

\section{(c) ${ }_{\mathrm{BY}}$}


https://doi.org/10.5194/bg-2020-311

This is just a preview and not the published preprint.

(c) Author(s) 2020. CC-BY 4.0 License.

(c) (i)

\subsection{Water quality indexes}

To investigate the effects of water quality on the GHG emissions from receiving water bodies, water quality indexes were calculated. By aggregating the measurements of multiple water quality parameters, water quality index as a single number can be used to assess the quality of a water resource for serving different purposes (Lumb et al., 2011). Prati and Oregon indexes were calculated and compared. Particularly, Prati index, developed by Prati et al. (1971), is often used to evaluate surface water quality with a consideration of numerous pollutants while Oregon Index was developed by Dunnette (1979) and then modified by Cude (2001) to express ambient water quality for general recreational use. In this study, we calculated the basic Prati index of each sampling site by accounting for DO saturation, COD, and $\mathrm{NH}_{4}^{+}$concentration, and a modified Oregon Index containing six variables, i.e. water temperature, $\mathrm{DO}, \mathrm{BOD}_{5}, \mathrm{pH}$, the total concentration of $\mathrm{NH}_{4}$ and $\mathrm{NO}_{3}$, and

180 TP concentration. Details of their calculation can be found in the Supplementary Material S3. According to the Prati index, water quality can be ranked as good quality, acceptable quality, polluted, heavily polluted, and very heavily polluted. Similarly, five water quality categories can be found according to Oregon index, i.e. excellent, good, fair, poor, very poor.

\subsection{Spatiotemporal variation of the GHG emissions}

To investigate the spatiotemporal variation of the GHG emissions, we applied a linear mixed model (LMM) in R (R Core

185 Team, 2014) using the Ime4 package (Bates et al., 2015). Not only accounting for fixed effects as linear regression models, LMM includes random effects that can take into account the spatiotemporal autocorrelations of observations (Dormann et al., 2007). Specifically, different sampling days and different tributaries were included to respectively assess the temporal and spatial variations of the collected samples. To do so, a three-level hierarchical mixed model was created, in which the unit of analysis, GHG emissions (level 1), is nested within rivers (level 2), which is in turn nested within the sampling days

190 (level 3). The GHG emissions were $\log 10$ transformed and standardized. A final check for normality was done by using Cleveland plots (Supplementary Material S4). Moreover, homogeneity was checked via the residuals of the fitted model (Supplementary Material S5) while the assumption of multicollinearity was omitted due to the absence of fixed parameters. The impacts of the spatiotemporal autocorrelation are represented by the mean of intraclass correlation coefficient (ICC) as a measure describing the homogeneity of the observed GHG emissions within given clusters, i.e. river and sampling day (West

195 et al., 2014). The ICC is determined via the variance components in the mixed model. Particularly, the sampling-day-level ICC $\left(I C C_{d a y}\right)$ was calculated by dividing the variance of the random sampling-day effects $\left(\sigma_{s d}^{2}\right)$ by the total random variation, consisting of $\sigma_{s d}^{2}$, the variance of the random effects associated with rivers nested within sampling campaign $\left(\sigma_{r}^{2}\right)$ and the variance of residual $\left(\sigma^{2}\right)$ :

$I C C_{d a y}=\frac{\sigma_{s d}^{2}}{\sigma_{s d}^{2}+\sigma_{r}^{2}+\sigma^{2}}$ 
https://doi.org/10.5194/bg-2020-311

This is just a preview and not the published preprint.

(c) Author(s) 2020. CC-BY 4.0 License.

(c) (i)

200 The value of $I C C_{d a y}$ is high when the total random variation is dominated by $\sigma_{s d}^{2}$, meaning that the GHG emissions measured among different sampling days tend to vary widely while these values among different rivers within a sampling campaign are relatively homogenous (Ho et al., 2018a). Similarly, the $I C C_{\text {river:day }}$ was calculated as follows.

$I C C_{\text {river }: d a y}=\frac{\sigma_{s d}^{2}+\sigma_{r}^{2}}{\sigma_{s d}^{2}+\sigma_{r}^{2}+\sigma^{2}}$

If the value of $I C C_{\text {river:day }}$ is higher than $I C C_{d a y}$, it means that there was a large variation in the GHG emissions within the

205 same river as $\sigma_{r}^{2}$ is high (Ho et al., 2018a).

\subsection{Random forests}

Random forests (RFs) were first offered by Ho (1995) and then improved by Breiman (2001) via using an ensemble of a large number of decision trees. Offering sufficient accuracy, simple implementation, and high robustness, RFs have been largely accepted in the machine learning community (Tyralis et al., 2019). RFs were implemented in R via the ranger package (Wright and Ziegler, 2017). To optimize the model, we tuned two essentials hyperparameters, including the minimal size of a node (min.node.size) and the number of candidate variables considered at each split (mtry) while the number of trees (num.trees) as a not tunable parameter was set at 500 (Probst et al., 2019). To do so, the mlr package of Bischl et al. (2016) was applied in parallel on eight CPU cores. The tuned model with optimal hyperparameters was run to identify the importance of variables for the GHG emissions. Permutation accuracy importance was preferred over the conventional

215 variable importance since it can deal with the drawbacks of the latter, e.g. bias towards continuous variables compared to categorical variables, and dividing up importance when variables are highly correlated (Strobl et al., 2007). The method of Janitza et al. (2018) for calculating permutation accuracy importance was applied in the ranger package.

\section{Results and discussion}

\subsection{Spatiotemporal variation of the GHG emissions}

220 We monitored five different tributaries in the Cuenca urban river system, including Cuenca, Machangara, Tarqui, Tomebamba, and Yanuncay, all showing strong variation in terms of GHG emissions (Figure 2). Converting the emissions to $\mathrm{CO}_{2}$ equivalent, it appeared that Tomebamba tributary was the largest GHG contributor, accounting for 59.6\% of the total emissions of the three gases per year from the whole river basin. Tarqui tributary ranked in the second place, contributing $21.2 \%$ of the total emissions per year, following by Cuenca tributary with $10.9 \%$. Machangara and Yanuncay generated in total less than $8 \%$ of the total emissions. Among the tributaries, the GHG emissions varied differently from one tributary to another. While high variation could be found in the largest GHG contributors, i.e. Tomebamba, Tarqui and Cuenca tributaries, the GHG emissions from Machangara and Yanuncay remained stable. Also noteworthy is that the mean value of the samples collected from Tomebamba, Tarqui and Cuenca were much higher than the median value, indicating the 
https://doi.org/10.5194/bg-2020-311

This is just a preview and not the published preprint.

(c) Author(s) 2020. CC-BY 4.0 License.

(c) (i)

emissions from the tributaries were positively skewed. The skewness was caused by several extremely high emissions released from the sampling sites located in the three tributaries.
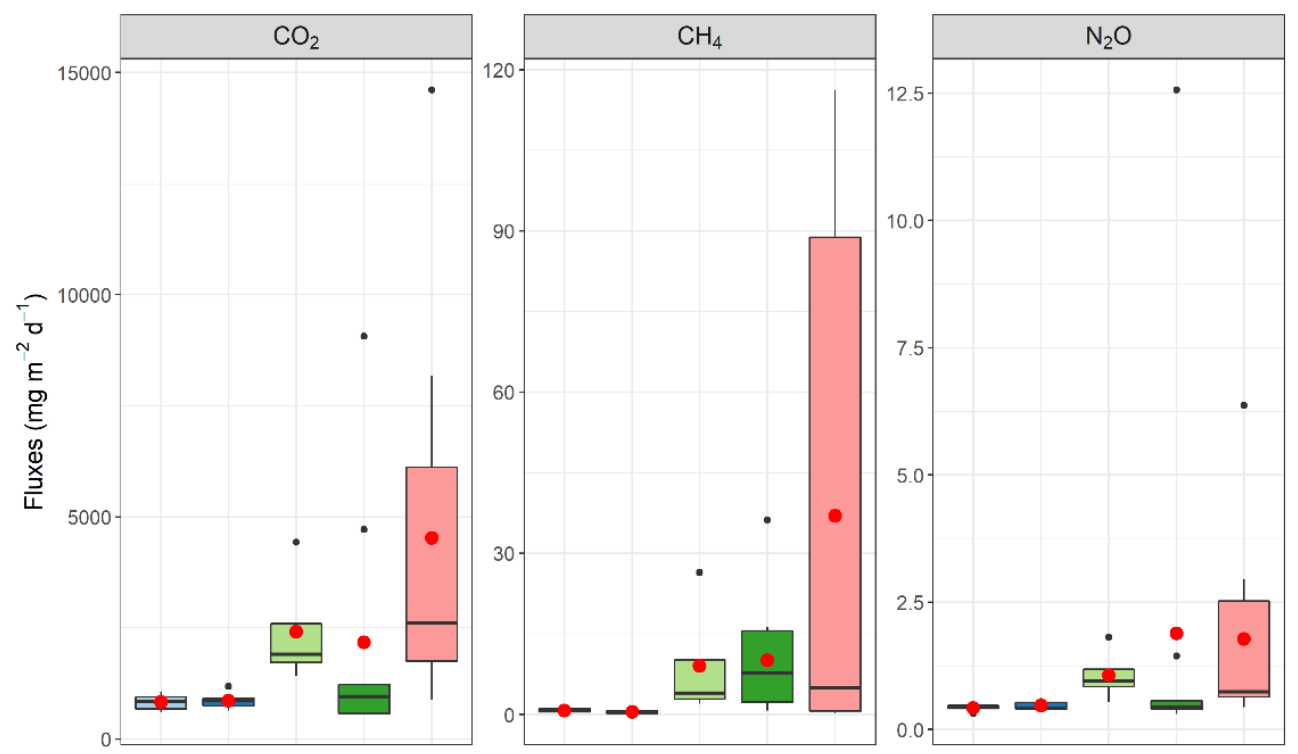

Tributaries

户 Machangara

Eanuncay

官 Cuenca

官 Tarqui

官 Tomebamba

Figure 2. Fluxes of the three greenhouse gases from the five tributaries of the Cuenca urban river system. Box plots display $\mathbf{1 0}^{\text {th }}$, $25^{\text {th }}, 50^{\text {th }}, 75^{\text {th }}$ and $90^{\text {th }}$ percentiles, and individual data points outside the $10^{\text {th }}$ and $90^{\text {th }}$ percentiles. Red dots represent the arithmetic mean of the fluxes from different tributaries.

High spatial variation of the GHG emissions was also indicated in the values of the obtained ICCs. Specifically, ICC river:day were 0.41 for $\mathrm{CO}_{2}, 0.47$ for $\mathrm{CH}_{4}$ and 0.24 for $\mathrm{N}_{2} \mathrm{O}$. These values were higher than the $I C C_{\text {day }}$, i.e. 0.19 for $\mathrm{CO}_{2}, 0.24$ for $\mathrm{CH}_{4}$ and 0.04 for $\mathrm{N}_{2} \mathrm{O}$. The differences between the two ICCs (around $20 \%$ of the total variation of the emissions) suggest a high spatial variation of the emissions from the tributaries. Plus, the values of $I C C_{d a y}$ suggest a higher diurnal variation of the $\mathrm{CO}_{2}$ and $\mathrm{CH}_{4}$ emissions compared to the stable $\mathrm{N}_{2} \mathrm{O}$ emissions across the sampling days since the variance of the random

240 diurnal effect explained only $4 \%$ of the total variation in the case of the $\mathrm{N}_{2} \mathrm{O}$ emissions. This contrast can be explained by substantial temporal variation of DO level observed in Cuenca in the previous studies (Ho et al., 2018a;Ho et al., 2018b). In particular, the production of $\mathrm{CO}_{2}$ and $\mathrm{CH}_{4}$ might depend stronger on the prevalence of $\mathrm{DO}$ as it controls the efficiency of anaerobic/anoxic processes, which are mainly responsible for releasing $\mathrm{CH}_{4}$, and highly correlated to the amount of $\mathrm{CO}_{2}$ released from the algal metabolism (Ho et al., 2019). While $\mathrm{N}_{2} \mathrm{O}$ emissions, which are mainly from nitrification (Wunderlin,

245 2013), could remain stable in this study due to the high DO level in the tributaries.

\subsection{Effect of water quality on the GHG emissions}

Prati and Oregon Indexes were applied to assess the effects of water quality on the GHG emissions from the receiving water bodies. According to the Prati Index, the rivers had higher water quality than the results obtained from the Oregon Index. 
https://doi.org/10.5194/bg-2020-311

This is just a preview and not the published preprint.

(c) Author(s) 2020. CC-BY 4.0 License.

(c) (i)

Particularly, 18 sampling sites were categorized in either good quality or acceptable quality following the Prati Index while

only two sites were considered either good or fair water quality according to the Oregon Index. The reason for this difference is because of a heavy penalty for high organic matter and nutrient concentrations in the Oregon Index. Particularly, on average, the Oregon subindex values calculated for water temperature, $\mathrm{DO}$, and $\mathrm{pH}$, were relatively high, from fair to excellent water quality, which was in contrast to the low values of the Oregon subindex calculated for $\mathrm{BOD}_{5}$, the total concentration of $\mathrm{NH}_{4}$ and $\mathrm{NO}_{3}$, and $\mathrm{TP}$ due to their high concentrations. These low subindex values made most of the sampling sites fall into the very poor category of water quality according to Oregon Index. Similarly, high concentrations of $\mathrm{NH}_{4}$ were the main reason for polluted sites in the calculation of the Prati Index.

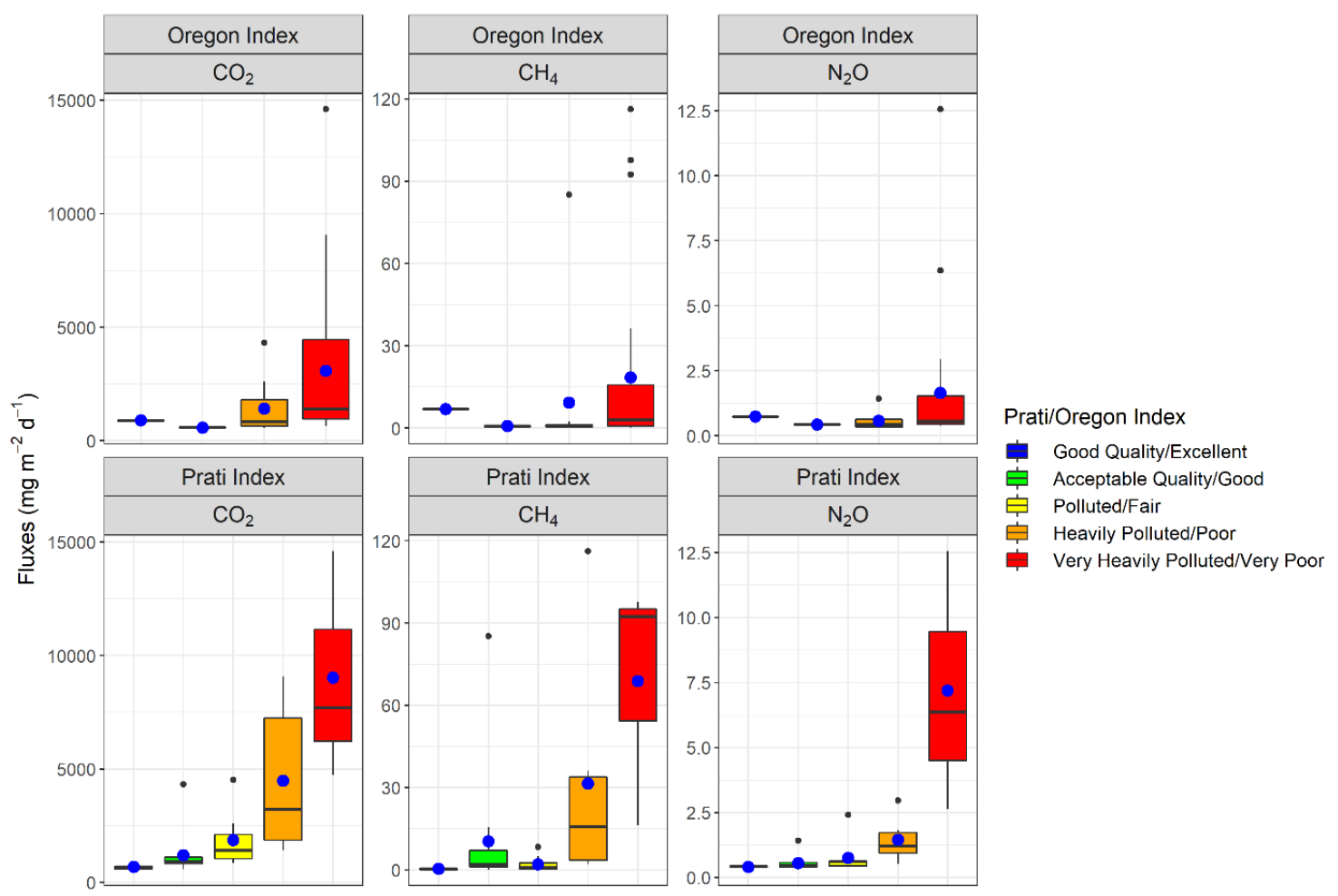

Figure 3. Fluxes of the three greenhouse gases from the Cuenca urban river system in different water quality categories using Oregon and Prati Indexes. Box plots display $10^{\text {th }}, 25^{\text {th }}, 50^{\text {th }}, 7^{\text {th }}$ and $90^{\text {th }}$ percentiles, and individual data points outside the $10^{\text {th }}$ and $90^{\text {th }}$ percentiles. Blue dots represent the mean of the fluxes in different water quality categories.

Figure 3 shows the emissions of the three GHGs in different water quality categories using the Oregon and Prati Indexes. By comparing the mean of the emissions in the categories, a clear pattern between water quality and GHG emissions can be observed, in which the more polluted the sampling sites were, the higher were their GHG emissions. According to the Prati Index, when the water quality became worse by one level, the average of their $\mathrm{CO}_{2}$ emissions was doubled up. In particular, the mean emissions from the sampling sites with good, acceptable, polluted, heavily polluted, and very heavily polluted 
https://doi.org/10.5194/bg-2020-311

This is just a preview and not the published preprint.

(c) Author(s) 2020. CC-BY 4.0 License.

water quality were $673.4 \pm 46.3,1203.7 \pm 290.7,1865.3 \pm 390.3,4483.1 \pm 1382.4$, and $9014.8 \pm 2926.9 \mathrm{mg}_{-} \mathrm{C} \mathrm{m} \mathrm{m}^{-2} \mathrm{~d}^{-1}$, respectively. Similarly, when river water quality deteriorated from acceptable quality to very heavily polluted quality, the $\mathrm{CH}_{4} \mathrm{emissions}$ increased by up to seven times while the $\mathrm{N}_{2} \mathrm{O}$ emissions boosted by 13 times. As a result, the GWP of the very heavily polluted sites were almost ten times higher than that value of the sites with acceptable water quality, indicating the considerably indirect negative impacts of polluted water bodies caused by anthropogenic activities. The GWP of the sites with different water quality based on Prati and Oregon Indexes can be found in Table 1. The emissions of contaminated sites were also much higher than the average estimated emissions of the global streams from the previous studies. It was estimated that the average $\mathrm{CO}_{2}$ and $\mathrm{CH}_{4}$ emissions of the global streams were $984.6 \pm 160.8 \mathrm{mg}_{-} \mathrm{C} \mathrm{m}^{-2} \mathrm{~d}^{-1}$ and $4.2 \pm 1.0 \mathrm{mg}-\mathrm{C} \mathrm{m} \mathrm{m}^{-2}$, respectively (Holgerson and Raymond, 2016) while their $\mathrm{N}_{2} \mathrm{O}$ emissions were around $0.89 \mathrm{mg}_{-} \mathrm{N} \mathrm{m}^{-2} \mathrm{~d}^{-1}(\mathrm{Beaulieu}$ et al., 2011). Counting from these estimations, the average estimated GWP from the global inland waters is around $1337.3 \pm 189.1$ mg $\mathrm{CO}_{2}$ equivalent $\mathrm{m}^{-2} \mathrm{~d}^{-1}$. By comparison, rivers with polluted water quality could release almost double the average estimated GWP while if their water quality worsened to very heavily polluted, the proportion was up to ten times. On the other hand, when the rivers had a good water quality according to Prati Index, their GWP was only approximately half of the average estimated GWP while the GWP of acceptable-water-quality rivers was similar to the average estimated GWP. Concerning the Oregon Index, apart from the abnormal high GHG emissions from one site with good water quality, it also appeared that when the more polluted sites were, the more GHGs could be produced. From fair to poor to very poor water quality, the $\mathrm{CO}_{2}$ emissions increased from 562.9 to 1404.4 to $3071.9 \mathrm{mg}-\mathrm{C} \mathrm{m}^{-2} \mathrm{~d}^{-1}$ while the $\mathrm{CH}_{4}$ emissions increased from 0.7 to 9.2 to $18.4 \mathrm{mg}-\mathrm{C} \mathrm{m}^{-2} \mathrm{~d}^{-1}$ and in case of the $\mathrm{N}_{2} \mathrm{O}$ emissions 0.4 to 0.6 to $1.6 \mathrm{mg}-\mathrm{N} \mathrm{m}^{-2} \mathrm{~d}^{-1}$. This clear pattern suggests a new method for the global estimation of GHG emissions from water bodies accounting for both the quantity of the water bodies and their water quality. In this study, Prati Index appeared to be an optimal choice for indicating the impacts of water quality on GHG emissions as illustrated in Table 1. Besides, as including only three variables, the application of Prati Index is more practical for the global estimation compared to Oregon Index.

Table 1. Global Warming Potential (GWP) of the sites with different water quality based on Prati and Oregon Indexes.

\begin{tabular}{|c|c|c|}
\hline $\begin{array}{c}\text { Water Quality Categories (Prati/Oregon } \\
\text { Index) }\end{array}$ & $\begin{array}{c}\text { GWP of the sites-Prati Index }(\mathrm{mg} \\
\left.\mathrm{CO}_{2} \text { equivalent } \mathrm{m}^{-2} \mathrm{~d}^{-1}\right)\end{array}$ & $\begin{array}{c}\text { GWP of the sites-Oregon Index (mg } \\
\left.\mathrm{CO}_{2} \text { equivalent } \mathrm{m}^{-2} \mathrm{~d}^{-1}\right)\end{array}$ \\
\hline Nood Quality/Excellent & $792.5 \pm 55.2$ & $695.2 \pm \mathrm{NA}$ \\
\hline Acceptable Quality/Good & $1441.9 \pm 507.6$ & $1270.7 \pm \mathrm{NA}$ \\
\hline Polluted/Fair & $2124.1 \pm 472.5$ & $1810.8 \pm 657.8$ \\
\hline Heavily Polluted/Poor & $5746.7 \pm 1977.3$ & $4021.6 \pm 1057.5$ \\
\hline
\end{tabular}

Not available (NA) values were because there were no site with excellent water quality, one site of good water quality, and one site of fair 
https://doi.org/10.5194/bg-2020-311

This is just a preview and not the published preprint.

(c) Author(s) 2020. CC-BY 4.0 License.

(c) (i)

\subsection{GHG emissions from different land-use types}

Hydro-morphological variables, including land-use types around the rivers, bank erosion rate, flow variation, pool-riffle class, and shading level, were also monitored via a sampling protocol. The detailed distribution of the variables across the five rivers is shown in the mosaic plots S6.1-S6.5 in Supplementary Material S6. Due to the large sampling area, land-use types widely varied while other variables remained relatively stable across the five tributaries. Particularly, urban and resident areas were dominant with around 55\% of the total sampling areas, while forest and agriculture occupied 8-11\% and $14-20 \%$, respectively. Minor sampling area was surrounded by industrial factories and construction sites, with less than 5\% each. Several riversides were next to the road, occupying 11-19\% of the total sampling area. The 0distribution of the landuse types was not evenly among the rivers. Intensive urban activities can be found near to the Cuenca and from the middle to the end of Tomebamba rivers. Conversely, Yanuncay and Machangara cross two natural reserves, i.e. Cajas National Park and the Machangara-Tomebamba protected forest, leading to their pristine water quality conditions natural (Jerves-Cobo et al., 2018b). Tarqui river locates near to agricultural irrigation and livestock production areas, causing their high nutrient and organic inputs (Jerves-Cobo et al., 2018b).
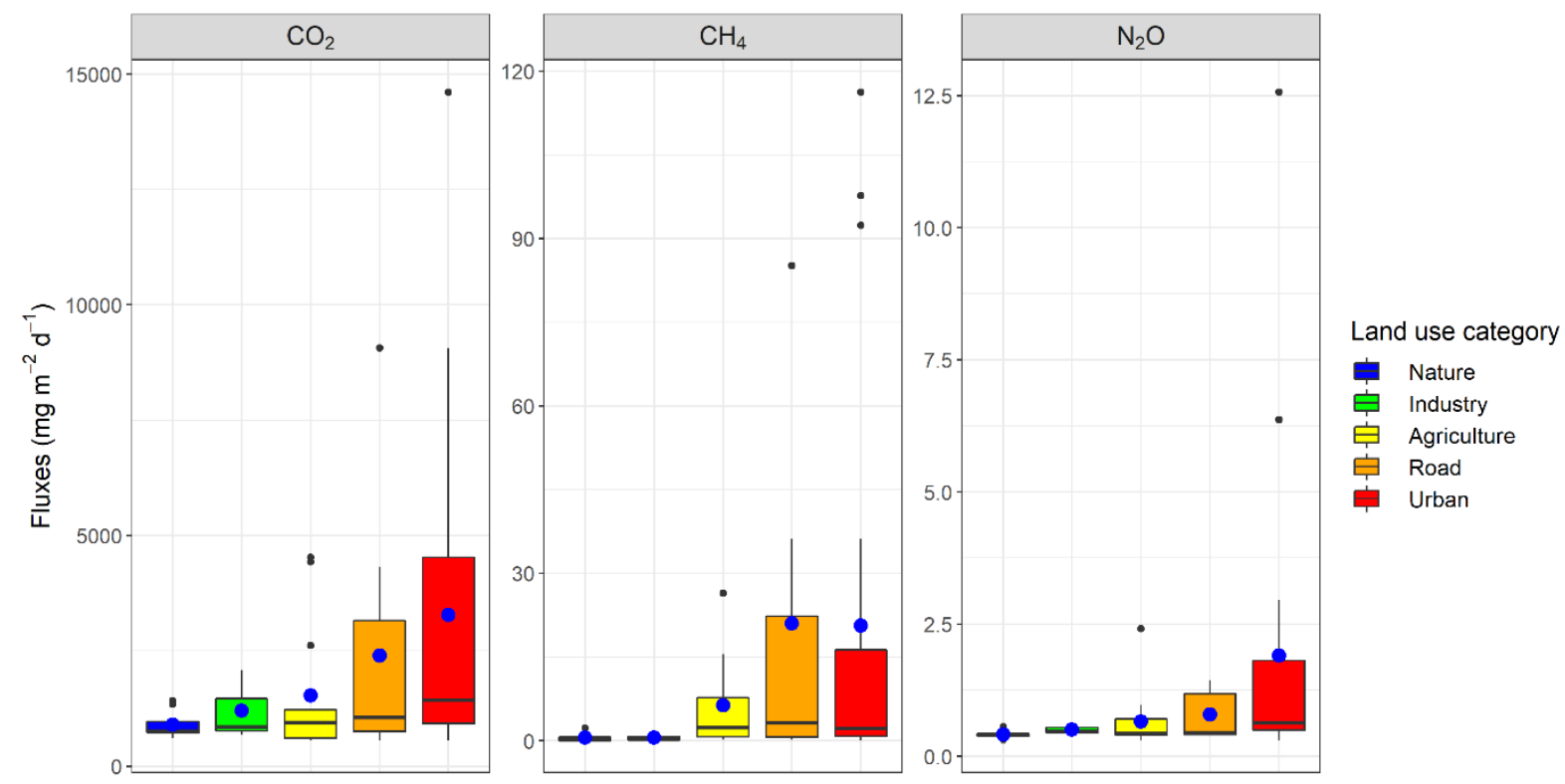

Nature

官 Industry

官 Agriculture

官 Road

Urban

Figure 4. Fluxes of the three greenhouse gases from the Cuenca urban river system in different land-use types. Box plots display $10^{\text {th }}, 25^{\text {th }}, \mathbf{5 0}^{\text {th }}, \mathbf{7 5}^{\text {th }}$ and $90^{\text {th }}$ percentiles, and individual data points outside the $10^{\text {th }}$ and $90^{\text {th }}$ percentiles. Blue dots represent the arithmetic mean of the fluxes from different land use categories.

Figure 4 shows an uneven distribution of the GHG emissions from the sampling sites close to different land-use types in the Cuenca urban river system. Looking at the mean of the emissions, it appeared that the sampling sites close to urban areas

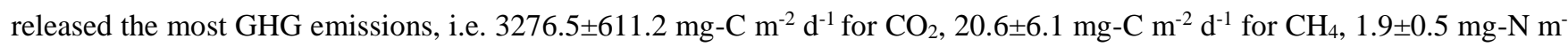


https://doi.org/10.5194/bg-2020-311

This is just a preview and not the published preprint.

(c) Author(s) 2020. CC-BY 4.0 License.

(c) (i)

${ }^{2} \mathrm{~d}^{-1}$ for $\mathrm{N}_{2} \mathrm{O}$, following by road, agriculture and industry areas. In contrast, nature areas appeared to affect the least the GHG emissions from the sites. Based on the emissions, the average GWP of the sites close to different land use types was calculated as shown in Table 2 . The highest GHG productivity from the sites close to urban areas significantly boosted their GWP to $4356.4 \pm 912.5 \mathrm{mg} \mathrm{CO}_{2}$ equivalent $\mathrm{m}^{-2} \mathrm{~d}^{-1}$ which was more than four time higher than the GWP of the sites close to natural areas. Similarly, the GWP of the sites close to roads or agricultural areas was triple and double that value of the natural sites. In fact, the calculated GWP of the sites close to urban, road, and agricultural areas were much higher compared to the average estimated GWP of global streams while the sites close to nature areas showed a smaller GWP by $25 \%$. These results highlight the indirect impacts of land-use change on increasing the GHG emissions from inland waters which are currently being omitted in land-use planning and resource management. The high emissions from sites close to urban, road, and agricultural areas were highly likely to be caused by the pollutants from the point discharges of combined sewer overflows and Ucubamba WWTP in the Tomebamba and Cuenca tributaries as well as the surface runoff from roads and arable areas. For example, being the second-largest GHG contributor, Tarqui tributary had high nutrient and organic matter load as its surrounded landscapes mainly occupied by agricultural irrigation and livestock production (Jerves-Cobo et al., 2018b). Hence, it can be concluded that land-use types, i.e. urban, transportation systems, and agriculture, can have considerable impacts on water quality and GHG emissions of the Cuenca river system. This conclusion is in line with previous studies on the role of the neighboring landscapes on GHG emissions from the rivers (Hotchkiss et al., 2015;Raymond et al., 2013;Rosamond et al., 2012). Smith et al. (2017) and, Yu and McCarl (2018) concluded that urban infrastructure greatly altered downstream water quality and was responsible for the variation of GHG emissions in rivers. Davidson et al. (2015) and Beaulieu et al. (2019) also reported that enhanced eutrophication in freshwater bodies will increase their $\mathrm{CH}_{4}$ emissions by $30-90 \%$ during the $21^{\text {st }}$ century. Hence, it is important to consider the considerable, but often omitted, impact of human intervention on the GHG emissions from rivers via the alteration of nutrient loads and compositions.

Table 2. Global Warming Potential (GWP) of the sites connected with different land use types

\begin{tabular}{|c|c|}
\hline Land use types & GWP of the sites $\left(\mathrm{mg} \mathrm{CO}_{2}\right.$ equivalent $\left.\mathrm{m}^{-2} \mathrm{~d}^{-1}\right)$ \\
\hline Nature & $1024.2 \pm 121.8$ \\
\hline Industry & $1354.5 \pm 472.7$ \\
\hline Agriculture & $1890.1 \pm 495.6$ \\
\hline Road & $3197.1 \pm 1104.7$ \\
\hline Urban & $4356.4 \pm 912.5$ \\
\hline
\end{tabular}

\subsection{Main important variable on the variation of the GHG emissions}

335 In contrast to general machine learning tools focusing mostly on forecasting and prediction over-explanation, random forests allow for whitening the black-box with explicit interpretation of the obtained result through variable importance metrics 
https://doi.org/10.5194/bg-2020-311

This is just a preview and not the published preprint.

(c) Author(s) 2020. CC-BY 4.0 License.

(c) (i)

(Tyralis et al., 2019). In this case, permutation accuracy importance indicated the role of a variable in changing the model prediction of the GHG emissions. From Figure 5, DO appeared to be the most important factor in the production of GHGs in the Cuenca urban river basin. As mentioned previously, the DO level is a main controlling factor of anaerobic and anoxic processes and highly correlated to algal metabolism, which can explain its first rank in the list of the variables. Moreover, $\mathrm{N}_{2} \mathrm{O}$ is mainly produced from nitrification and denitrification processes whose efficiency can strongly be affected by the availability of oxygen (Castro-Barros et al., 2017). Concerning the $\mathrm{N}_{2} \mathrm{O}$ pathways of ammonia-oxidizing bacteria, during nitrifier nitrification processes, high $\mathrm{O}_{2}$ can enhance the contribution of hydroxylamine oxidation to $\mathrm{N}_{2} \mathrm{O}$ production while nitrifier denitrification is more active at oxygen limiting conditions (Schreiber et al., 2012). Moreover, a low amount of oxygen causes the emissions of $\mathrm{N}_{2} \mathrm{O}$ during denitrification as $\mathrm{N}_{2} \mathrm{O}$ reductase is more sensitive to be inhibited by oxygen compared to nitrite reductase and nitric oxide reductase (Kampschreur et al., 2009;Schreiber et al., 2012). Additionally, an extra pathway of $\mathrm{N}_{2} \mathrm{O}$ emissions from the metabolism of green algae, which may be affected by nitrite concentration and photosynthesis repression, are not yet fully understood (Ho and Goethals, 2020b).

Nutrient concentrations also appeared as major important factors in GHG production in the rivers. The variation of $\mathrm{NH}_{4}^{+}$ 350 concentration, the input of nitrification process, affected the emissions of $\mathrm{N}_{2} \mathrm{O}$ the most while $\mathrm{NO}_{3}{ }^{-}$, the input of denitrification process, appeared to be a marginal controlling factor. IPCC assumed that nitrification produces $\mathrm{N}_{2} \mathrm{O}$ twice as much as denitrification in streams and rivers (Mosier et al., 1998). This assumption is highly likely true in this study as oxygen was relatively prevalent in the Cuenca urban river system, facilitating nitrification but inhibiting its consecutive steps in biological nitrogen removal processes. Beaulieu et al. (2011) and Rosamond et al. (2012) found no relationship between

$355 \mathrm{~N}_{2} \mathrm{O}$ yield and stream water $\mathrm{NO}_{3}{ }^{-}$and less than $1 \%$ of stream water nitrate subject to direct denitrification is converted to $\mathrm{N}_{2} \mathrm{O}$. Conversely, higher denitrification rates were found in the river floodplains as a result of nitrate-rich and oxygen-poor conditions in the flood water and flooded sediment (Venterink et al., 2003;Forshay and Stanley, 2005), which, however, was not the case in this study. Equally important, $\mathrm{NH}_{4}{ }^{+}$, the main nutrient input for algae, mosses, and macrophytes in the rivers, plays an important role in the variation of $\mathrm{CO}_{2}$ emissions from rivers as plant nutrition partly determines the ratio of 360 photosynthesis to respiration. Theoretically, a high amount of ammonium can be an inhibitor for anaerobic processes but only in very high concentrations from 4.0 to $5.7 \mathrm{~g} \mathrm{NH}_{3}-\mathrm{N} \mathrm{L}^{-1}$ (Chen et al., 2008), which is not the case in this study. Despite being on the list of the most important factors on the emissions of all the three gases, $\mathrm{NO}_{2}^{-}$presence in the environment is often unstable and in a very low concentration, e.g. smaller than $0.01 \mathrm{mg} \mathrm{L}^{-1}$ in this study. This condition is attributed to the fact that $\mathrm{NO}_{2}{ }^{-}$is an intermediate oxidation state of nitrogen in the oxidation of ammonia to nitrate (nitrification), and in the 365 reduction of nitrate process (denitrification) (Hu et al., 2016). Also noteworthy is that COD appeared to have a relatively marginal impact on the variation of the three GHGs. The correlation coefficients between COD and the emissions of $\mathrm{CH}_{4}$ and $\mathrm{CO}_{2}$ were weak, i.e. 0.53 and 0.44 , which is not in line with the conclusion on significant correlations between them in the study of Yang et al. (2015). Other factors indicating flow characteristics, such as turbidity, average velocity, average depth, and water temperature also affected the variation of the GHG emissions from the rivers. Particularly, the turbulence of the river flow affected the variation of $\mathrm{CH}_{4}$ the most among the three gases. 
https://doi.org/10.5194/bg-2020-311

This is just a preview and not the published preprint.

(c) Author(s) 2020. CC-BY 4.0 License.

(c) (i)
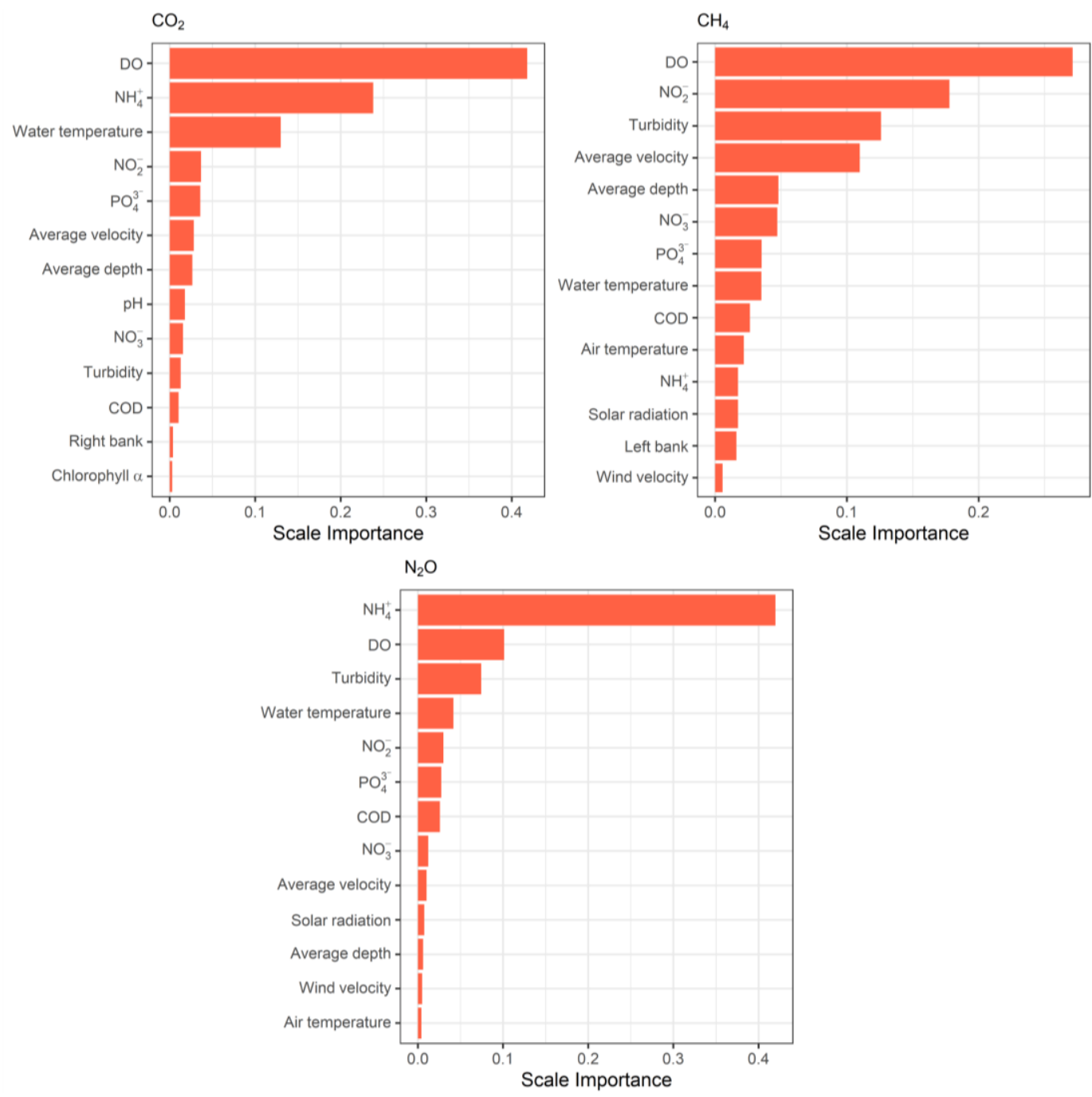

Figure 5. Permutation accuracy importance of variables in the variation of GHG emissions from the Cuenca urban river system.

\subsection{Sources of the GHG emissions}

Figure 6 shows the average of the estimated total GHG emissions per year from each tributary. Note that although the standard error of the mean of the samples was used to indicate the uncertainty of the estimates, substantial variation of the emissions can be induced by the fluctuation of water quality, and river and climatic conditions during a year. It appeared that Tomebamba and Tarqui were the major contributors to GHG emissions in the Cuenca urban river system. Particularly, Tomebamba tributary released the most with $186.8 \pm 51.8 \mathrm{Gg} \mathrm{CO}_{2} \mathrm{yr}^{-1}, 1.5 \pm 0.6 \mathrm{Gg} \mathrm{CH}_{4} \mathrm{yr}^{-1}$, and $73.1 \pm 22.2 \mathrm{Mg} \mathrm{N}_{2} \mathrm{O} \mathrm{yr}{ }^{-1}$, accounting for $57.0 \%$ of the total $\mathrm{CO}_{2}$ emissions, $76.7 \%$ of the total $\mathrm{CH}_{4}$ emissions, and $44.6 \%$ of the total $\mathrm{N}_{2} \mathrm{O}$ emissions from the whole river basin. Details of the fraction of the total GHG emissions per year from different tributaries can be found 
https://doi.org/10.5194/bg-2020-311

This is just a preview and not the published preprint.

(c) Author(s) 2020. CC-BY 4.0 License.

(c) (i)

in Supplementary Material S7. High amount of GHG emissions from Tomebamba was caused by its high emission rate, i.e. $4527.9 \pm 1256.3 \mathrm{mg}-\mathrm{C} \mathrm{m}^{-2} \mathrm{~d}^{-1}, 37.0 \pm 14.7 \mathrm{mg}-\mathrm{C} \mathrm{m}^{-2} \mathrm{~d}^{-1}$, and $1.78 \pm 0.53 \mathrm{mg}-\mathrm{N} \mathrm{m}^{-2} \mathrm{~d}^{-1}$ for $\mathrm{CO}_{2}, \mathrm{CH}_{4}$, and $\mathrm{N}_{2} \mathrm{O}$ emissions, respectively (Supplementary Material S7). These emission rates were more than double the mean GHG emission rates from the whole Cuenca urban river. The high emission rates were induced by the emissions of the sites 15,16 , and 35 in this tributary. These contaminated sites, considered very heavily polluted by both indexes, had a high concentration of $\mathrm{NH}_{4}{ }^{+}$of more than $15 \mathrm{mg} \mathrm{L}^{-1}$ and a thick anaerobic sludge layer of 5-20 cm, causing low DO concentration of 2.7-3.4 mg L-1. Note that due to the exclusion of ebullition in the flux calculation, the estimated $\mathrm{CH}_{4}$ could be underestimated. High $\mathrm{CH}_{4}$ emission rate of $3.04 \mathrm{mg}-\mathrm{C} \mathrm{m}^{-2} \mathrm{~d}^{-1}$ also found in site 34 in Tomebamba tributary although we observed thin sludge layers and the highest wind velocity $\left(5.8 \mathrm{~m} \mathrm{~s}^{-1}\right)$ in this site.

390 As the largest tributary, Tarqui ranked the second-highest contributor, releasing $110.4 \pm 48.9 \mathrm{Gg} \mathrm{CO}_{2} \mathrm{yr}^{-1}, 0.5 \pm 0.2 \mathrm{Gg} \mathrm{CH}_{4} \mathrm{yr}^{-}$ 1, and $95.6 \pm 67.9 \mathrm{Mg} \mathrm{N}_{2} \mathrm{O} \mathrm{yr}{ }^{-1}$, accounting for $18.3 \%, 13.9 \%$, and $31.5 \%$, of the total emissions of $\mathrm{CO}_{2}, \mathrm{CH}_{4}$, and $\mathrm{N}_{2} \mathrm{O}$, respectively. The high value of the mean of the total $\mathrm{N}_{2} \mathrm{O}$ emissions from Tarqui was induced by an exceptionally high $\mathrm{N}_{2} \mathrm{O}$ emissions from site 02 , i.e. $12.6 \mathrm{mg}-\mathrm{N} \mathrm{m}^{-2} \mathrm{~d}^{-1}$. Note that this site was categorized in the worst water quality category by both indexes having the highest concentrations of $\mathrm{TN}, \mathrm{NH}_{4}$, turbidity, and TDS, together with low DO level of $5.54 \mathrm{mg} \mathrm{L}^{-1}$. Site

39522 was another polluted site in Tarqui tributary also characterized by very stagnant water with flow velocity of $0.01 \mathrm{~m} \mathrm{~s}^{-1}$ and low DO level of $2.7 \mathrm{mg} \mathrm{L}^{-1}$. This site was the second and the fifth largest contributor of $\mathrm{CO}_{2}$ and $\mathrm{CH}_{4}$, respectively. Conversely, being the least contaminated tributaries, Machangara and Yanuncay released less than 15 times the total GHG emissions from Tomebamba and Tarqui tributaries, in which each accounted for around $5 \%$ of the total $\mathrm{CO}_{2}$ and $\mathrm{N}_{2} \mathrm{O}$ emissions, and $0.7 \%$ of total $\mathrm{CH}_{4}$ emissions from the whole basin.

400 Note that despite being the smallest tributary, high GHG emissions were found in Cuenca tributary with $84.5 \pm 23.8 \mathrm{Gg} \mathrm{CO}_{2}$ $\mathrm{yr}^{-1}, 0.3 \pm 0.2 \mathrm{Gg} \mathrm{CH}_{4} \mathrm{yr}^{-1}$, and $37.2 \pm 9.4 \mathrm{Mg} \mathrm{N}_{2} \mathrm{O} \mathrm{yr}{ }^{-1}$, accounting for $13.1 \%$ of the total $\mathrm{CO}_{2}$ emissions, $8.1 \%$ of the total $\mathrm{CH}_{4}$ emissions, and $11.5 \%$ of the total $\mathrm{N}_{2} \mathrm{O}$ emissions from the whole river basin. The main reason for these high emissions can be because of the discharge from the Ucubamba WWTP to Cuenca tributary, raising the concentration of $\mathrm{NH}_{4}{ }^{+}$and $\mathrm{PO}_{4}{ }^{3-}$ by five- and two-fold, respectively, i.e. above $5 \mathrm{mg} \mathrm{NH}_{4}{ }^{+}-\mathrm{N} \mathrm{L}^{-1}$ and $0.7 \mathrm{mg} \mathrm{PO}_{4}{ }^{3-}-\mathrm{P} \mathrm{L}^{-1}$. The high concentration of nutrients with 405 the overgrowth of algae were also found in the discharge of Ucubamba WWTP in the previous studies (Ho, 2018;JervesCobo et al., 2020a). This result highlights the concern about the increasing GHG emissions from the WWTPs and the potential impact of its discharge on the GHG emissions from the receiving water bodies (Mannina et al., 2018). 
https://doi.org/10.5194/bg-2020-311

This is just a preview and not the published preprint.

(c) Author(s) 2020. CC-BY 4.0 License.

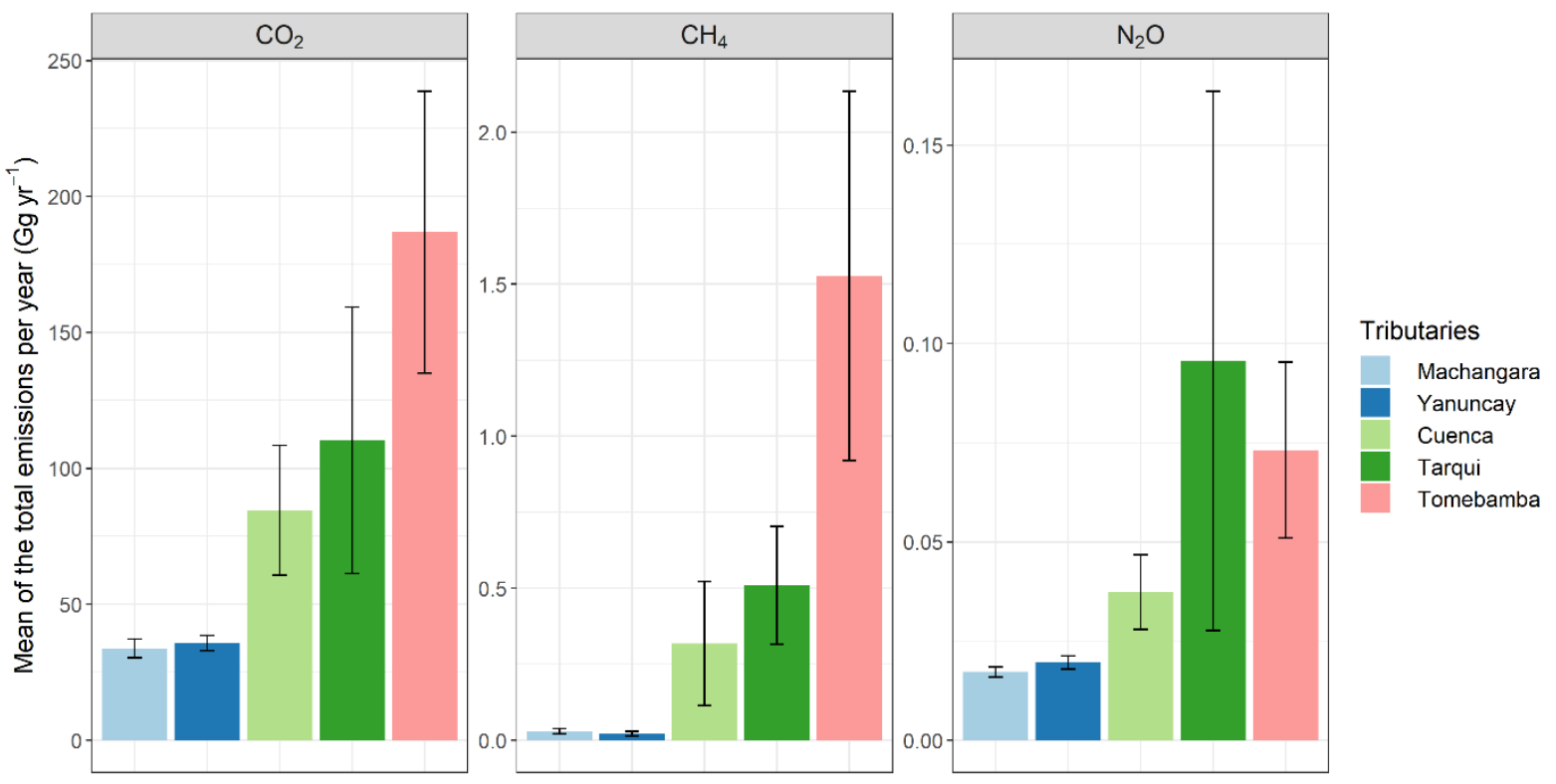

Figure 6. Mean of the estimated total emissions per year from the five tributaries of the Cuenca urban river system. Error bars represent the standard error of the mean of the sample.

\section{Conclusion}

- Being the most polluted tributaries, Tomebamba and Tarqui, released $75 \%$ of the total emissions of $\mathrm{CO}_{2}$ and $\mathrm{N}_{2} \mathrm{O}$, and $90 \%$ of the total $\mathrm{CH}_{4}$ emissions, which was in contrast to the emissions from Machangara and Yanuncay, i.e. only $5 \%$ and $0.7 \%$, respectively. High peaks of GHG emissions were found in the Cuenca tributary after the discharge of the Ucubamba WWTP.

- By using Prati and Oregon Indexes, a clear pattern between water quality and GHG emissions was observed, in which the more polluted the sampling sites were, the higher were their GHG emissions. Specifically, when river water deteriorated from acceptable quality to very heavily polluted quality, their GWP increased by ten times. Compared to the estimated emissions from the global streams, rivers with polluted water can release almost double the average estimated GWP while if their water quality worsened to very heavily polluted, the proportion was up to ten times. On the other hand, when the rivers had good water quality according to Prati Index, their GWP was only approximately half of the average estimated GWP while the GWP of acceptable-water-quality rivers was similar to this value. These results suggest that to estimate of the global emissions from inland waters, both their quantity and water quality should be considered for which Prati Index is recommended over the other.

- The study found that adjacent land-use types, i.e. urban, transportation systems, and agriculture, had significantly contributed to the increase in the GHG emissions from the rivers in Cuenca. Specifically, the GWP of the sites close 
https://doi.org/10.5194/bg-2020-311

This is just a preview and not the published preprint.

(C) Author(s) 2020. CC-BY 4.0 License.

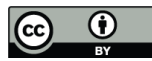

to urban areas was four time higher than the GWP of the sites close to natural areas. Similarly, the GWP of the sites close to roads or agricultural areas was triple and double the GWP of the natural sites. Note that the later was smaller than the average estimated GWP of global streams by $25 \%$. These results highlight the indirect impacts of land-use change on increasing the GHG emissions from inland waters which are currently being omitted in land-use planning and resource management.

- By applying random forests, the main important factors on GHG emissions were identified. Dissolved $\mathrm{O}_{2}$ appeared to be the most important factor for the variation of the $\mathrm{CO}_{2}$ and $\mathrm{CH}_{4}$ emissions and the second most important factor for the variation of the $\mathrm{N}_{2} \mathrm{O}$ emissions. Ammonium, together with variables indicating flow characteristics, such as turbidity, average velocity, average depth, and water temperature, also affected the variation of the GHG emissions. Conversely, a margin effect of organic matter concentration on the GHG emissions was found, which is in contrast to their strong correlation obtained from the previous studies. This result implies a higher role of (partial) nitrification compared to denitrification in producing $\mathrm{N}_{2} \mathrm{O}$ in these river systems.

\section{Acknowledgment}

440 This research was performed in the context of the VLIR Ecuador Biodiversity Network project. This project was funded by the Vlaamse Interuniversitaire Raad-Universitaire Ontwikkelingssamenwerking (VLIR-UOS), which supports partnerships between universities and university colleges in Flanders and the South. We thank Carlos Santiago Deluquez, Caio Neves, Paula Avila, Juan Enrique Orellana, and Kate Pesantez for their contributions during the sampling campaign. We are grateful to the Water and Soil Quality Analysis Laboratory of the University of Cuenca for their supports in our analyses.

\section{References}

Altman, D. G., and Bland, J. M.: Statistics notes - Standard deviations and standard errors, Brit Med J, 331, 903-903, DOI 10.1136/bmj.331.7521.903, 2005.

Bastviken, D., Cole, J., Pace, M., and Tranvik, L.: Methane emissions from lakes: Dependence of lake characteristics, two regional assessments, and a global estimate, Global Biogeochem Cy, 18, Artn Gb4009. 10.1029/2004gb002238, 2004.

450 Bastviken, D., Tranvik, L. J., Downing, J. A., Crill, P. M., and Enrich-Prast, A.: Freshwater Methane Emissions Offset the Continental Carbon Sink, Science, 331, 50-50, 10.1126/science.1196808, 2011.

Bates, D., Machler, M., Bolker, B. M., and Walker, S. C.: Fitting Linear Mixed-Effects Models Using lme4, J Stat Softw, 67, $1-48,2015$.

Beaulieu, J. J., Tank, J. L., Hamilton, S. K., Wollheim, W. M., Hall, R. O., Mulholland, P. J., Peterson, B. J., Ashkenas, L. 455 R., Cooper, L. W., Dahm, C. N., Dodds, W. K., Grimm, N. B., Johnson, S. L., McDowell, W. H., Poole, G. C., Valett, H. M., Arango, C. P., Bernot, M. J., Burgin, A. J., Crenshaw, C. L., Helton, A. M., Johnson, L. T., O'Brien, J. M., Potter, J. D., Sheibley, R. W., Sobota, D. J., and Thomas, S. M.: Nitrous oxide emission from denitrification in stream and river networks, P Natl Acad Sci USA, 108, 214-219, 10.1073/pnas.1011464108, 2011. 
https://doi.org/10.5194/bg-2020-311

This is just a preview and not the published preprint.

(c) Author(s) 2020. CC-BY 4.0 License.

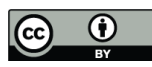

Beaulieu, J. J., DelSontro, T., and Downing, J. A.: Eutrophication will increase methane emissions from lakes and impoundments during the 21st century, Nat Commun, 10, ARTN 1375 10.1038/s41467-019-09100-5, 2019.

Bischl, B., Lang, M., Kotthoff, L., Schiffner, J., Richter, J., Studerus, E., Casalicchio, G., and Jones, Z. M.: mlr: Machine Learning in R, The Journal of Machine Learning Research, 17, 5938-5942, 2016.

Breiman, L.: Random Forests, Machine Learning, 45, 5-32, 10.1023/a:1010933404324, 2001.

Butman, D., and Raymond, P. A.: Significant efflux of carbon dioxide from streams and rivers in the United States, Nat

Geosci, 4, 839-842, 10.1038/NGEO1294, 2011.

Castro-Barros, C. M., Ho, L. T., Winkler, M. K. H., and Volcke, E. I. P.: Integration of methane removal in aerobic anammox-based granular sludge reactors, Environ Technol, 1-11, 10.1080/09593330.2017.1334709, 2017.

Chang, W., Cheng, J., Allaire, J., Xie, Y., and McPherson, J.: Package 'shiny', http://citeseerx.ist.psu.edu/viewdoc/download, 2015.

470 Chen, Y., Cheng, J. J., and Creamer, K. S.: Inhibition of anaerobic digestion process: A review, Bioresource Technol, 99, 4044-4064, DOI 10.1016/j.biortech.2007.01.057, 2008.

Cole, J. J., and Caraco, N. F.: Atmospheric exchange of carbon dioxide in a low-wind oligotrophic lake measured by the addition of SF6, Limnol Oceanogr, 43, 647-656, DOI 10.4319/lo.1998.43.4.0647, 1998.

Cude, C. G.: Oregon Water Quality Index: A tool for evaluating water quality management effectiveness, J Am Water

Resour As, 37, 125-137, DOI 10.1111/j.1752-1688.2001.tb05480.x, 2001.

Daelman, M. R., van Voorthuizen, E. M., van Dongen, L. G., Volcke, E. I., and van Loosdrecht, M. C.: Methane and nitrous oxide emissions from municipal wastewater treatment - results from a long-term study, Water Sci Technol, 67, 2350-2355, 10.2166/wst.2013.109, 2013.

Damanik-Ambarita, M. N., Boets, P., Nguyen Thi, H. T., Forio, M. A. E., Everaert, G., Lock, K., Musonge, P. L. S., 480 Suhareva, N., Bennetsen, E., Gobeyn, S., Ho, T. L., Dominguez-Granda, L., and Goethals, P. L. M.: Impact assessment of local land use on ecological water quality of the Guayas river basin (Ecuador), Ecol Inform, 48, 226-237, https://doi.org/10.1016/j.ecoinf.2018.08.009, 2018.

Davidson, T. A., Audet, J., Svenning, J. C., Lauridsen, T. L., Sondergaard, M., Landkildehus, F., Larsen, S. E., and Jeppesen, E.: Eutrophication effects on greenhouse gas fluxes from shallow-lake mesocosms override those of climate warming, Global Change Biol, 21, 4449-4463, 10.1111/gcb.13062, 2015.

Dormann, C. F., McPherson, J. M., Araujo, M. B., Bivand, R., Bolliger, J., Carl, G., Davies, R. G., Hirzel, A., Jetz, W., Kissling, W. D., Kuhn, I., Ohlemuller, R., Peres-Neto, P. R., Reineking, B., Schroder, B., Schurr, F. M., and Wilson, R.: Methods to account for spatial autocorrelation in the analysis of species distributional data: a review, Ecography, 30, 609628, 10.1111/j.2007.0906-7590.05171.x, 2007.

490 Dunnette, D.: A geographically variable water quality index used in Oregon, Journal (Water Pollution Control Federation), 53-61, 1979.

Forshay, K. J., and Stanley, E. H.: Rapid nitrate loss and denitrification in a temperate river floodplain, Biogeochemistry, 75, 43-64, 10.1007/s10533-004-6016-4, 2005.

Gallo, E. L., Lohse, K. A., Ferlin, C. M., Meixner, T., and Brooks, P. D.: Physical and biological controls on trace gas fluxes

in semi-arid urban ephemeral waterways, Biogeochemistry, 121, 189-207, 10.1007/s10533-013-9927-0, 2014.

Goldenfum, J. A.: Challenges and solutions for assessing the impact of freshwater reservoirs on natural GHG emissions, Ecohydrology \& Hydrobiology, 12, 115-122, 10.2478/v10104-012-0011-5, 2012.

Ho, L., Pham, D., Van Echelpoel, W., Muchene, L., Shkedy, Z., Alvarado, A., Espinoza-Palacios, J., Arevalo-Durazno, M., Thas, O., and Goethals, P.: A Closer Look on Spatiotemporal Variations of Dissolved Oxygen in Waste Stabilization Ponds 
https://doi.org/10.5194/bg-2020-311

This is just a preview and not the published preprint.

(c) Author(s) 2020. CC-BY 4.0 License.

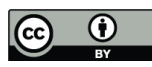

Ho, L., and Goethals, P.: Research hotspots and current challenges of lakes and reservoirs: a bibliometric analysis, Scientometrics, 10.1007/s11192-020-03453-1, 2020a.

Ho, L., and Goethals, P. L. M.: Municipal wastewater treatment with pond technology: Historical review and future outlook, Ecol Eng, 148, 105791, https://doi.org/10.1016/j.ecoleng.2020.105791, 2020b.

505 Ho, L. T.: Integrating statistical and mechanistic modeling approaches for optimization of wastewater treatment ponds, PhD, Department of Animal Sciences and Aquatic Ecology, Ghent University, Ghent, Belgium, 2018.

Ho, L. T., Pham, D. T., Van Echelpoel, W., Alvarado, A., Espinoza-Palacios, J. E., Arevalo-Durazno, M. B., and Goethals, P. L. M.: Exploring the influence of meteorological conditions on the performance of a waste stabilization pond at high altitude with structural equation modeling, Water Sci Technol, 78, 37-48, 10.2166/wst.2018.254, 2018b.

510 Ho, L. T., Alvarado, A., Larriva, J., Pompeu, C., and Goethals, P.: An integrated mechanistic modeling of a facultative pond: Parameter estimation and uncertainty analysis, Water Res, 151, 170-182, 10.1016/j.watres.2018.12.018, 2019.

Ho, T. K.: Random decision forests, Proceedings of 3rd International Conference on Document Analysis and Recognition, 1995, 278-282 vol.271,

Holgerson, M. A., and Raymond, P. A.: Large contribution to inland water $\mathrm{CO} 2$ and $\mathrm{CH} 4$ emissions from very small ponds, 515 Nat Geosci, 9, 222-U150, 10.1038/Ngeo2654, 2016.

Hotchkiss, E. R., Hall Jr, R. O., Sponseller, R. A., Butman, D., Klaminder, J., Laudon, H., Rosvall, M., and Karlsson, J.: Sources of and processes controlling $\mathrm{CO} 2$ emissions change with the size of streams and rivers, Nat Geosci, 8, 696, 10.1038/ngeo2507. 2015.

$\mathrm{Hu}$, M. P., Chen, D. J., and Dahlgren, R. A.: Modeling nitrous oxide emission from rivers: a global assessment, Global Change Biol, 22, 3566-3582, 10.1111/gcb.13351, 2016.

IPCC: Climate Change 2014: Synthesis Report, Contribution of Working Groups I, II and III to the Fifth Assessment Report of the Intergovernmental Panel on Climate Change Geneva, Switzerland9789291691432, 2014.

Janitza, S., Celik, E., and Boulesteix, A. L.: A computationally fast variable importance test for random forests for highdimensional data, Adv Data Anal Classi, 12, 885-915, 10.1007/s11634-016-0276-4, 2018.

525 Jerves-Cobo, R., Cordova-Vela, G., Iniguez-Vela, X., Diaz-Granda, C., Van Echelpoel, W., Cisneros, F., Nopens, I., and Goethals, P. L. M.: Model-Based Analysis of the Potential of Macroinvertebrates as Indicators for Microbial Pathogens in Rivers, Water-Sui, 10, Artn 37510.3390/W10040375, 2018a.

Jerves-Cobo, R., Lock, K., Van Butsel, J., Pauta, G., Cisneros, F., Nopens, I., and Goethals, P. L. M.: Biological impact assessment of sewage outfalls in the urbanized area of the Cuenca River basin (Ecuador) in two different seasons,

530 Limnologica, 71, 8-28, https://doi.org/10.1016/j.limno.2018.05.003, 2018b.

Jerves-Cobo, R., Benedetti, L., Amerlinck, Y., Lock, K., De Mulder, C., Van Butsel, J., Cisneros, F., Goethals, P., and Nopens, I.: Integrated ecological modelling for evidence-based determination of water management interventions in urbanized river basins: Case study in the Cuenca River basin (Ecuador), Sci Total Environ, 709, 136067, https://doi.org/10.1016/j.scitotenv.2019.136067, 2020a.

535 Jerves-Cobo, R., Forio, M. A. E., Lock, K., Van Butsel, J., Pauta, G., Cisneros, F., Nopens, I., and Goethals, P. L. M.: Biological water quality in tropical rivers during dry and rainy seasons: A model-based analysis, Ecological Indicators, 108, UNSP 105769. 10.1016/j.ecolind.2019.105769, 2020b.

Kampschreur, M. J., Temmink, H., Kleerebezem, R., Jetten, M. S. M., and van Loosdrecht, M. C. M.: Nitrous oxide emission during wastewater treatment, Water Res, 43, 4093-4103, DOI 10.1016/j.watres.2009.03.001, 2009.

540 Kaushal, S. S., McDowell, W. H., and Wollheim, W. M.: Tracking evolution of urban biogeochemical cycles: past, present, and future, Biogeochemistry, 121, 1-21, 10.1007/s10533-014-0014-y, 2014. 
https://doi.org/10.5194/bg-2020-311

This is just a preview and not the published preprint.

(C) Author(s) 2020. CC-BY 4.0 License.

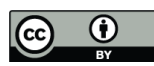

Kling, G. W., Kipphut, G. W., and Miller, M. C.: The Flux of CO2 and CH4 from Lakes and Rivers in Arctic Alaska, Hydrobiologia, 240, 23-36, Doi 10.1007/Bf00013449, 1992.

Kroeze, C., Dumont, E., and Seitzinger, S. P.: New estimates of global emissions of N2O from rivers and estuaries, Environmental Sciences, 2, 159-165, 10.1080/15693430500384671, 2005.

Liss, P. S., and Slater, P. G.: Flux of Gases across the Air-Sea Interface, Nature, 247, 181-184, 10.1038/247181a0, 1974.

Lumb, A., Sharma, T. C., and Bibeault, J. F.: A Review of Genesis and Evolution of Water Quality Index (WQI) and Some Future Directions, Water Qual Expos Hea, 3, 11-24, 10.1007/s12403-011-0040-0, 2011.

Mannina, G., Butler, D., Benedetti, L., Deletic, A., Fowdar, H., Fu, G. T., Kleidorfer, M., McCarthy, D., Mikkelsen, P. S., 550 Rauch, W., Sweetapple, C., Vezzaro, L., Yuan, Z. G., and Willems, P.: Greenhouse gas emissions from integrated urban drainage systems: Where do we stand?, J Hydrol, 559, 307-314, 10.1016/j.jhydrol.2018.02.058, 2018.

Meybeck, M.: Carbon, Nitrogen, and Phosphorus Transport by World Rivers, Am J Sci, 282, 401-450, DOI 10.2475/ajs.282.4.401, 1982.

Mosier, A., Kroeze, C., Nevison, C., Oenema, O., Seitzinger, S., and van Cleemput, O.: Closing the global N(2)O budget: nitrous oxide emissions through the agricultural nitrogen cycle Nutr Cycl Agroecosys, 52, 225-248, Doi 10.1023/A:1009740530221, 1998.

Musenze, R. S., Werner, U., Grinham, A., Udy, J., and Yuan, Z. G.: Methane and nitrous oxide emissions from a subtropical estuary (the Brisbane River estuary, Australia), Sci Total Environ, 472, 719-729, 10.1016/j.scitotenv.2013.11.085, 2014.

Parsons, M., Thoms, M., and Norris, R.: Australian river assessment system: AusRivAS physical assessment protocol, 560 Monitoring river health initiative technical report, 22, 2002.

Prati, L., Pavanello, R., and Pesarin, F.: Assessment of Surface Water Quality by a Single Index of Pollution, Water Res, 5, 741-+, Doi 10.1016/0043-1354(71)90097-2, 1971.

Probst, P., Wright, M. N., and Boulesteix, A.-L.: Hyperparameters and tuning strategies for random forest, Wiley Interdisciplinary Reviews: Data Mining and Knowledge Discovery, 9, e1301, 10.1002/widm.1301, 2019.

565 R Core Team: R: A Language and Environment for Statistical Computing. ISBN 3-900051-07-0, Vienna, Austria, 2014.

Raven, P. J., Fox, P., Everard, M., Holmes, N. T. H., and Dawson, F. H.: River habitat survey: A new system for classifying rivers according to their habitat quality, Freshwater Quality: Defining the Indefinable?, 215-234, 1997.

Raymond, P. A., and Cole, J. J.: Gas exchange in rivers and estuaries: Choosing a gas transfer velocity, Estuaries, 24, 312317, Doi 10.2307/1352954, 2001.

570 Raymond, P. A., Hartmann, J., Lauerwald, R., Sobek, S., McDonald, C., Hoover, M., Butman, D., Striegl, R., Mayorga, E., Humborg, C., Kortelainen, P., Durr, H., Meybeck, M., Ciais, P., and Guth, P.: Global carbon dioxide emissions from inland waters, Nature, 503, 355-359, 10.1038/nature12760, 2013.

Rosamond, M. S., Thuss, S. J., and Schiff, S. L.: Dependence of riverine nitrous oxide emissions on dissolved oxygen levels, Nat Geosci, 5, 715-718, 10.1038/Ngeo1556, 2012.

575 Sander, R.: Compilation of Henry's law constants (version 4.0) for water as solvent, Atmos Chem Phys, 15, 4399-4981, 10.5194/acp-15-4399-2015, 2015.

Schimel, D. S.: Terrestrial ecosystems and the carbon cycle, Global Change Biol, 1, 77-91, 10.1111/j.13652486.1995.tb00008.x, 1995.

Schreiber, F., Wunderlin, P., Udert, K. M., and Wells, G. F.: Nitric oxide and nitrous oxide turnover in natural and 580 engineered microbial communities: biological pathways, chemical reactions, and novel technologies, Front Microbiol, 3, ARTN 372. 10.3389/fmicb.2012.00372, 2012. 
https://doi.org/10.5194/bg-2020-311

This is just a preview and not the published preprint.

(c) Author(s) 2020. CC-BY 4.0 License.

(c) (i)

Smith, R. M., Kaushal, S. S., Beaulieu, J. J., Pennino, M. J., and Welty, C.: Influence of infrastructure on water quality and greenhouse gas dynamics in urban streams, Biogeosciences, 14, 2831-2849, 10.5194/bg-14-2831-2017, 2017.

Stanley, E. H., Casson, N. J., Christel, S. T., Crawford, J. T., Loken, L. C., and Oliver, S. K.: The ecology of methane in

streams and rivers: patterns, controls, and global significance, Ecol Monogr, 86, 146-171, 10.1890/15-1027, 2016.

Strobl, C., Boulesteix, A. L., Zeileis, A., and Hothorn, T.: Bias in random forest variable importance measures: Illustrations, sources and a solution, Bmc Bioinformatics, 8, Artn 25. 10.1186/1471-2105-8-25, 2007.

Tuser, M., Picek, T., Sajdlova, Z., Juza, T., Muska, M., and Frouzova, J.: Seasonal and Spatial Dynamics of Gas Ebullition in a Temperate Water-Storage Reservoir, Water Resour Res, 53, 8266-8276, 10.1002/2017WR020694, 2017.

590 Tyralis, H., Papacharalampous, G., and Langousis, A.: A Brief Review of Random Forests for Water Scientists and Practitioners and Their Recent History in Water Resources, Water-Sui, 11, ARTN 910. 10.3390/w11050910, 2019.

van't Hoff, J. H.: Etudes de dynamique chimique, Muller, 1884.

Venterink, H. O., Hummelink, E., and Van den Hoorn, M. W.: Denitrification potential of a river floodplain during flooding with nitrate-rich water: grasslands versus reedbeds, Biogeochemistry, 65, 233-244, Doi 10.1023/A:1026098007360, 2003.

595 Wang, X. F., He, Y. X., Yuan, X. Z., Chen, H., Peng, C. H., Yue, J. S., Zhang, Q. Y., Diao, Y. B., and Liu, S. S.: Greenhouse gases concentrations and fluxes from subtropical small reservoirs in relation with watershed urbanization, Atmos Environ, 154, 225-235, 10.1016/j.atmosenv.2017.01.047, 2017.

Wanninkhof, R.: Relationship between Wind-Speed and Gas-Exchange over the Ocean, J Geophys Res-Oceans, 97, 73737382, Doi 10.1029/92jc00188, 1992.

600 West, B. T., Welch, K. B., and Galecki, A. T.: Linear mixed models: a practical guide using statistical software, CRC Press, 2014.

Wojciechowski, J., Hopkins, A. M., and Upton, R. N.: Interactive Pharmacometric Applications Using R and the Shiny Package, Cpt-Pharmacomet Syst, 4, 146-159, 10.1002/psp4.21, 2015.

Wright, M. N., and Ziegler, A.: ranger: A Fast Implementation of Random Forests for High Dimensional Data in C plus plus and R, J Stat Softw, 77, 1-17, 10.18637/jss.v077.i01, 2017.

Wunderlin, P.: Mechanisms of $\mathrm{N}_{2} \mathrm{O}$ production in biological wastewater treatment from pathway identification to process control, PhD ETH Zurich, ETH Zurich, ETH Zurich, 2013.

Yang, S. S., Chen, I. C., Liu, C. P., Liu, L. Y., and Chang, C. H.: Carbon dioxide and methane emissions from Tanswei River in Northern Taiwan, Atmos Pollut Res, 6, 52-61, 10.5094/Apr.2015.007, 2015.

610 Yu, C. H., and McCarl, B. A.: The Water Implications of Greenhouse Gas Mitigation: Effects on Land Use, Land Use Change, and Forestry, Sustainability-Basel, 10, ARTN 2367. 10.3390/su10072367, 2018. 